\title{
Consumer Participation and Effectiveness of the No Plastic Bag Day Program in Malaysia
}

\author{
Shahariah Asmuni, Jamaliah Mhd. Khalili, \\ Nur Bashirah Hussin, Zahariah Mohd Zain \\ Center of Economics and Finance, Faculty of Business Management, \\ UniversitiTeknologi MARA, Shah Alam, Selangor, Malaysia \\ shaha154@salam.uitm.edu.my
}

\begin{abstract}
In 2011, Malaysia introduced the No Plastic Bag Day program where stores charge a levy of MYR0.20 (USD0.06) on ach plastic bag used. Based on observations, participation in the program is moderate, with $47.7 \%$ of consumers willingly paid the levy. Those who bring their own bags are mostly female, Malay and Chinese customers. Consumers in the central region tend to avoid the levy. Based on findings of study, the NPBD program is $52.3 \%$ effective. In order to discourage the use of plastic bags, the government may need to reconsider the amount of levy charged on consumers.
\end{abstract}

Keywords:public participation; effectiveness; plastic bag; levy

eISSN 2398-4295 @ 2018. The Authors. Published for AMER ABRA cE-Bs by e-International Publishing House, Ltd., UK. This is an open-access article under the CC BY-NC-ND license (http://creativecommons.org/licenses/bync-nd/4.0/). Peer-review under responsibility of AMER (Association of Malaysian Environment-Behaviour Researchers), ABRA (Association of Behavioural Researchers on Asians) and cE-Bs (Centre for EnvironmentBehaviour Studies), Faculty of Architecture, Planning \& Surveying, Universiti Teknologi MARA, Malaysia.

DOI: http://dx.doi.org/10.21834/ajbes.v3i10.78 


\subsection{Introduction}

The plastic bag is a popular means of carrying goods when making purchases in Malaysia. The retail business use plastic carrier bags, as they are inexpensive and weightless (Jalil, Mian, \&Rahman, 2013). Trillion plastic bags are used as carrier bags everywhere in the world annually (Miller, R.M., 2012).

Plastic bags that end up in landfills bring significant environmental burden. When thrown into landfills, plastic waste takes from 400 to 1000 years to degrade (Musa et al., 2013; Bashir, 2013). Plastic waste also brings nuisance to the human sight. When not properly recycled, it amasses as litter in public areas (Ayalon et al., 2009). With their aerodynamic shape and low recycling rate (Godman, 2013), used plastic bags pose problems beyond their simple use.

Aquatic animals perceive plastic bags as food and digest them, causing harm to the digestive system (Ayalon et al., 2009; Godman, 2013). Death to animals from swallowing plastic bags is higher than from diseases in most African countries (Bashir, 2013). Plastic waste, when broken down, can also affect hormone levels of animals when it passes through the food chain, which can eventually affect humans (Musa et al., 2013).

To reduce the problems from the nonchalant use of plastic bags, countries such as Australia, Italy, United States and Tanzania have resorted to the imposition of tax or a ban on the production and use of plastic bags (Jalil et al., 2013). Regulations such as the requirement for retailers to restrict the use of plastic bags for only those who are willing to pay a levy is a method implemented to discourage plastic bag use. Regulation plays a significant role in inducing ethical commitment of manufacturers (Zaman, 2012). This ethical commitment can also explain the pro-environmental behavior of the general public.

Malaysians in average produce 19,000 tonnes of solid waste annually and plastic waste represents $24 \%$ of total solid waste. In 2011, Malaysia introduced the No Plastic Bag Day (NPBD) program to discourage the use of plastic bags for carrying items purchased from shopping stores. In the program, participating stores charge a levy of MYR0.20 (USD0.06) for each new plastic bag requested by customers.

The use of product tax as a price signal can be an important instrument to change consumer behavior. The level of consumer acceptance to the implementation of product tax is crucial to its success (Convery, McDonnell, \& Ferreira, 2007). However, while there have been many attempts to reduce the use of plastic carrier bags, not many of them have been assessed in terms of their success (Poortinga, Whitmarsh, \& Suffolk, 2013).

Malaysia's effort to reduce the use of plastic bags began when the Penang state in 2009 banned the use of plastic bags from shopping stores on Mondays. In 2010, Selangor state discouraged the use of plastic bags through levy on Saturdays. The Penang state government ultimately imposes the ban on the use of plastic bags on any day.

The federal government through the Ministry of Domestic Trade, Cooperative and Consumerism (MDTCC) in 2011 launched the NPBD Campaign throughout Malaysia for each Saturday. The objective is to reduce the use of plastic bags in retail outlets, supermarkets, and hypermarkets in order to reduce its negative impact on the environment. Participating stores encourage customers to bring their own carrier bags or purchase eco- 
friendly bags. Some stores provide paper or synthetic fiber carrier bags that can be reused. The ban on plastic bags is reinforced with a levy of MYR0.20 (or USD0.06) for every plastic bag used. The environmental tax works as a disincentive to deter a buyer from a behavior that may lead to environmental degradation. The tax money is either channeled to charity (Hong, 2011) or is used by the store to implement environmental conservation activities.

The purpose of this study is to evaluate on whether the NPBD program is successful in reducing the use of plastic bags in shopping stores in Malaysia. The result of study is useful in assisting policymakers to evaluate the success of the program objectively. Specifically, the study aims to determine the effectiveness of the program through analyzing consumer response on the levy charged on plastic bags.

\subsection{Literature Review}

Environmental initiatives by the government will not be effective unless accompanied by public participation (Eden, 1996). Public participation in environmental management brings numerous benefits and people are aware of them (Lim, 2012). A number of studies have dealt with participation of the public in pro-environmental behavior (Peerapun, 2012). A large number has focused on recycling behavior (Asmuni, Khalili, \&Zain, 2012; Singhirunnusorn et al., 2012).

There are a few studies that analyze the effectiveness of levy on plastic bags. One study concluded that the plastic bag levy has not been effective as consumers continue to forget to bring their own plastic bags for shopping (Zen et al., 2013). Poortinga et al. (2013) described the effectiveness of the charge similarly, which is through the habit change of consumers towards consciously bringing their own carrier bags. The use of a levy takes a utilitarian approach, which can be effective in promoting a change of habit (Chan, Wong, \& Leung, 2007).

In England, the levy was very effective as the habit of bringing own bags rises from $62 \%$ to $82 \%$ when they introduced the charge (Poortinga et al., 2013). Convery et al., (2007) assessed the effect of a plastic bag levy and found the impact to be natural or positive to retailers as costs of implementing levy is lower than savings from not giving plastic bags. The levy is also found to add to consumers' shopping expenditure.

Dikgang, Leiman, \&Visser, (2012) measures the price elasticity of demand for plastic bags and found the elasticity value to be low and positive. The study concluded that the levy is not effective as consumers are unaware of changes in price of plastic bags. Furthermore, plastic bag substitutes are very few and do not serve all purposes.

Ayalon et al. (2009) measures the effectiveness of levy on plastic bags in Israel. Estimated levy is NIS1 and plastic bag use is reduced to $12 \%$ after levy. As levy amount increases, usage rate falls. However, at NIS4, consumption of plastic bags remains unchanged at $6 \%$. This may represent plastic bags that are the best carrier options for trash or to carry wet items used for outdoor activities such as picnicking. The issue of plastic bag in Israel is on 'flying bags', which cause unsightly litter. If a large portion of the 'flying bags' is represented by the $6 \%$ use of plastic bags, then the levy of NIS 4 can be ineffective. Plastic 
bag levy may not be effective when the actual people who create the problem of this litter in open spaces are not the ones who pay for the tax (Ayalon et al., 2009).

\subsection{Methodology}

This study analyses consumer's pro-environmental behavior when faced with a plastic bag levy. 45 trained observers gather information on participation in the NPBD program in October of 2013. Using convenient sampling technique, observations are taken from retail, minimarket and supermarket stores located close to the area of residence of observers. Data collected includes characteristics of consumers and information on the use of carrier bags by each observed consumer.

Information on payments made for plastic bag levy measures the effectiveness of the plastic bag levy in reducing the use of plastic bags. The analysis includes an investigation into how much the consumers paid for the levy. The study assumes its own criteria in deciding the effectiveness of the NPBD program. If the number of customers who take plastic bags and pay the levy is $75 \%$ or more, then the program is considered effective. If the percentage is $50 \%$ or only slightly more than $50 \%$, we consider the tax not very effective. If it is below $50 \%$, the tax is not effective.

Analysis of study is limited to variables that can only be observed during a purchase transaction. As the method of obtaining data is through observation, information such as race and age group is subjected to observers' opinions. Observations made do not capture motives of consumers in their participation in the NPBD program. However, the selection of the method of observation reflects actual behavior of consumers in making purchases. Thus actual decision involving the use of plastic bags can be directly observed.

\subsection{Results and Discussions}

From 560 observations carried out, $68.8 \%$ were done in supermarkets or hypermarkets, and the remaining in minimarkets, specialized stores, and convenience stores. $60.4 \%$ of the observations come from the central region. The result of study shows that $28.8 \%$ of all consumers bring their own carrier bags and $19.1 \%$ leave stores without a bag.

Participation of consumers in the NPBD program is moderate, given that almost $50 \%$ of them willingly paid the charges for plastic bags. If the store can provide more reusable bags and make them more accessible to consumers, the number of consumers who will purchase reusable bags and reduce their use of plastic bags will increase. With more facilities for consumers to carry out pro-environmental behavior, more convenience can be enjoyed, and more participation can be expected (Latif, Omar, Bidin, \&Awang, 2012). 
Table 1. Consumer Participation in the NPBD Program

\begin{tabular}{|c|c|c|c|c|}
\hline & \multicolumn{2}{|l|}{$\begin{array}{l}\text { Frequency } \\
(\mathrm{N}=560)\end{array}$} & \multicolumn{2}{|c|}{ Valid Percent (100\%) } \\
\hline & Yes & No & Yes & No \\
\hline $\begin{array}{l}\text { Does customer bring his/her own bag to put items } \\
\text { bought from store? }\end{array}$ & 161 & 399 & 28.75 & 71.25 \\
\hline \multirow[b]{2}{*}{$\begin{array}{l}\text { Customer's reaction when asked to pay } 20 \text { cents for a } \\
\text { plastic bag: }\end{array}$} & Frequency & $\begin{array}{c}\text { Valid } \\
\text { Percent }\end{array}$ & & \\
\hline & & & & \\
\hline Not relevant (brings own bag) & 16128.74 & & & \\
\hline Do not pay for a bag and leave without a bag & 10719.1 & & & \\
\hline Customer pays for the plastic bag (tax) & 26747.7 & & & \\
\hline Customer buys eco-friendly bag from the store & 254.5 & & & \\
\hline
\end{tabular}

(Source: Authors)

From table 2, those who bring their own bags are mostly female and they are mostly Malays and Chinese. The percentages of those who do not bring their bags are more than double for Malays when compared to Chinese.

Table 2. Chi-Square Dependency Test between Bringing Own Bags and Socio-Demography

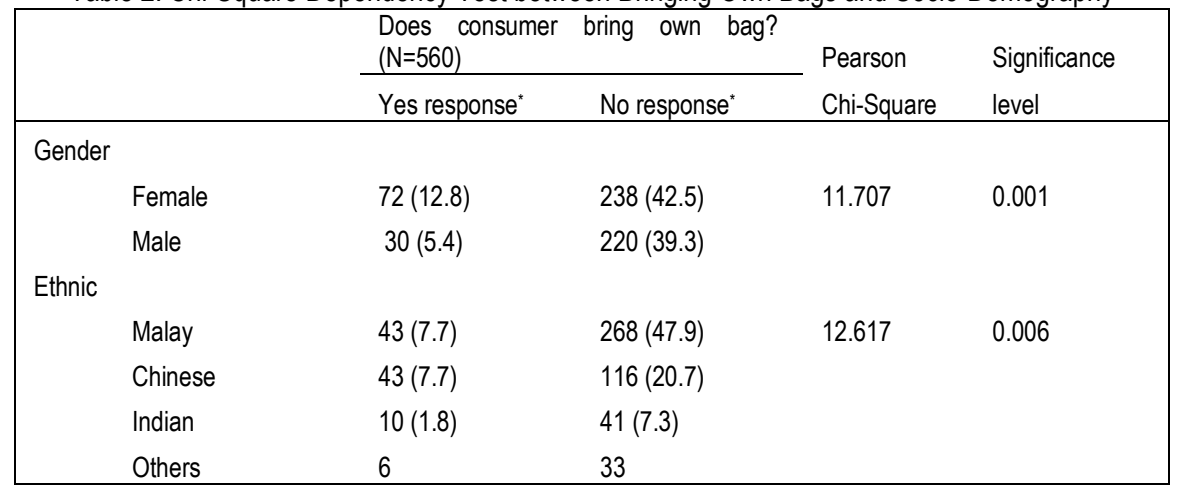

Percentage in parenthesis

(Source: Authors)

The amount of plastic bag levy paid is dependent on the ethnicity of consumers (table 3). The ethnic group most associated with avoiding the levy is the Chinese at $59 \%$ of all Chinese consumers. The ethic group with the highest percentage paying for 1 bag (RM0.20 levy) is the Indian. For more levy paid (greater than or equal to RM0.40, which is equivalent to 2 or more bags), the Malays and Chinese are more likely to pay the levy than the Indians. 
Age group is significantly associated with the amount of plastic bag levy consumers pay (table 3). Children, which refer to school age consumers, tend not to pay the levy. Young adults (college students and young workers) may either pay or avoid the levy. Middle age people and the elderly tend to avoid the levy.

There is a significant association between the amount that consumers pay for plastic bag levy and location of stores. Half of consumers in the central region (Selangor and federal territories of Putrajaya and Kuala Lumpur), choose to avoid the levy. This region represents the wealthiest region in the Peninsular. Consumers may have chosen not to pay due to their awareness of the NPBD program. Another reason could be the proximity of store locations to parking areas. Thus, consumers may not need bags as they can carry their purchase items using store trolleys. However, half of consumers in the central region paid the levy.

Table 3. Chi-Square Dependency Test Between the Amount of Plastic Bag Levy with SocioDemography

\begin{tabular}{|c|c|c|c|c|c|c|c|}
\hline & & \multicolumn{4}{|c|}{ Amount of plastic bag tax consumer is paying $(\mathrm{N}=560)$} & \multirow{2}{*}{$\begin{array}{l}\text { Pearson } \\
\text { Chi-Square }\end{array}$} & \multirow[t]{2}{*}{ Sig. } \\
\hline & & None & MYR0.20 & MYR0.40 & $>$ MYR0.40 & & \\
\hline \multicolumn{8}{|l|}{ Ethnicity } \\
\hline & Malay & $157(51 \%)$ & $83(27 \%)$ & $46(15 \%)$ & $25(8 \%)$ & 17.502 & 0.041 \\
\hline & Chinese & $94(59 \%)$ & $36(23 \%)$ & $16(10 . \%)$ & $13(8 \%)$ & & \\
\hline & Indian & $23(45 \%)$ & $22(43 \%)$ & $3(6 \%)$ & $3(6 \%)$ & & \\
\hline & Others & 19 & 10 & 3 & 7 & & \\
\hline \multicolumn{8}{|l|}{ Age group } \\
\hline & Children & 16 & 4 & 0 & 1 & 18.499 & 0.030 \\
\hline & Young adult & 126 & 83 & 29 & 14 & & \\
\hline & Middle age & 137 & 60 & 36 & 31 & & \\
\hline & Elderly & 14 & 4 & 3 & 2 & & \\
\hline \multicolumn{8}{|c|}{ Region of store location } \\
\hline & Central & 169 & 94 & 41 & 34 & 17.816 & 0.037 \\
\hline & South & 58 & 21 & 9 & 6 & & \\
\hline & North & 23 & 25 & 10 & 4 & & \\
\hline & East-coast & 43 & 11 & 8 & 4 & & \\
\hline & & & & & & & \\
\hline
\end{tabular}

In the northern region (Penang and Kedah), the number of those who pay for levy exceeds those who avoid it. For the southern (Johor, Malacca and Negeri Sembilan) and east coast (Kelantan) regions, the number of those avoiding the levy is higher than those who pay at least MYR0.20. This finding shows that consumers in relatively poor regions are willing to pay for the tax. The amount of levy (MRY0.20 per plastic bag) may be regarded as 
too low to consumers in this region, resulting in consumers paying for plastic bags instead of bringing their own bags.

\section{Effectiveness of Plastic Bag Tax}

Whether or not consumers pay for the plastic bag levy measures the level of effectiveness of plastic bag levy in reducing the use of plastic bags. The implementation of NPBD program excludes wet markets and restaurants as these outlets sell prepared food and wet grocery items such as poultry. The use of reusable grocery bags in these outlets are not encouraged due to hygiene reasons.

Consumers in stores participating in the NPBD program might also be purchasing wet groceries. Thus, if the use of plastic bags is for carrying wet groceries, then the use of at least a single plastic bag by a customer for this reason should not be regarded as contributing to the ineffectiveness of the NPBD program.

Table 4 depicts how much consumers paid for the plastic bag levy. From 560 consumers observed, 293 consumers (52.3\%) avoided paying the levy. These are consumers who decided that they either do not need bags, carry purchase items using hands, pockets, handbags, trolleys, baskets, boxes, paper bags supplied by the store, or they used reusable bags brought from the store or from home. From those who paid for the plastic bag levy, 151 consumers (27\%) made the payment for a single plastic bag. As the price of the bag is constant at MYR0.20 per bag, extra levy paid means extra bags requested. $12.1 \%$ of consumers paid for 2 plastic bags (MYR0.40) and $8.7 \%$ of consumers paid for MYR0.60 or more.

Table 4. Descriptive Summary of Plastic Bag Levy

\begin{tabular}{|lll|}
\hline $\begin{array}{l}\text { Total levy paid } \\
(\mathrm{MYR})\end{array}$ & $\begin{array}{l}\text { Frequency of consumers } \\
(\mathrm{N}=560)\end{array}$ & $\begin{array}{l}\text { Valid } \\
\text { percent }(100 \%)\end{array}$ \\
\hline 0.00 & 293 & 52.3 \\
0.20 & 151 & 27.0 \\
0.40 & 68 & 12.1 \\
0.60 & 19 & 3.4 \\
0.80 & 14 & 2.5 \\
1.00 & 9 & 1.6 \\
Above 1.00 & 6 & 1.2 \\
\hline
\end{tabular}

Based on the premise that the program is effective if consumers avoid using plastic bags at all when shopping, the NPBD program analysis in this study is $52.3 \%$ effective. However, if the use of one plastic bag is allowed to carry wet groceries, then the effectiveness of the program can be increased. Assuming $78.3 \%$ of those paying RM0.20 of levy (equivalent to 118 consumers) are those paying the charge to carry wet groceries, then the effectiveness 
of policy when ignoring the purchase of the first plastic bag is relatively high at $79.3 \%$. This covers $52.3 \%$ of consumers who avoids paying the levy and $27 \%$ of those paying levy for MYR0.20.

\subsection{Conclusion}

The initiation of the NPBD program is to reduce the use of plastic bags as carrier bags. The program has been $52.3 \%$ effective in making consumers avoid the use of plastic bags as this percentage represents those who resort to using reusable grocery bags or other means of carrying purchase items.

To increase the level of effectiveness and participation in the program, public awareness can be increased. One way is to generate a culture of bringing own bags when shopping and making the practice more convenient, especially to males as they are less likely to bring bags. The social media can be used to inform and educate the public on the importance of a change of habit towards using less plastic bags.

In order to discourage the use of plastic bags during shopping, the government may need to reconsider the amount of levy charged on consumers. From the study, $47.7 \%$ of consumers paid the levy in exchange for plastic bags. As the amount of levy depends on race, location and age group, some of these factors can be considered when determining the effective amount of levy. For a wealthier region in the country such as the central region, higher levy may be considered.

Future research can look into whether reasons for bringing own bags when shopping are dependent on ethnicity. It is also interesting to find out if the NPBD program has managed to instill the pro-environmental habit of using less plastic bags through observing purchase habits during days other than the NPB days.

\section{Acknowledgement}

The authors would like to thank the Ministry of Higher Education and UniversitiTeknologi MARA for funding this research under the Research Acculturation Grant Scheme.

\section{References}

Ayalon, O., Goldrath, T., Rosenthal, G., \& Grossman, M. (2009). Reduction of plastic carrier bag use: An analysis of alternatives in Israel. Waste management (New York, N.Y.), 29(7), 2025-32. doi:10.1016/j.wasman.2009.02.016

Bashir, N. H. H. (2013). Plastic problem in Africa. The Japanese Journal of Veterinary Research, 61 Suppl, S1-11. Retrieved from http://www.ncbi.nlm.nih.gov/pubmed/23631147

Chan, R. Y. K., Wong, Y. H., \& Leung, T. K. P. (2007). Applying Ethical Concepts to the Study of "Green" Consumer Behavior: An Analysis of Chinese Consumers' Intentions to Bring their Own Shopping Bags. Journal of Business Ethics, 79(4), 469-481. doi:10.1007/s10551-007-9410-8 
Asmuni, S., et.al. / Asian Journal of Behavioural Studies (AjBeS), 3(10) Mar / Apr 2018 (p.33-41)

Convery, F., McDonnell, S., \& Ferreira, S. (2007). The most popular tax in Europe? Lessons from the Irish plastic bags levy. Environmental and Resource Economics, 38(1), 1-11. doi:10.1007/s10640-006-9059-2

Dikgang, J., Leiman, A., \& Visser, M. (2012). Elasticity of demand, price and time: lessons from South Africa's plastic-bag levy. Applied Economics, 44(26), 3339-3342. doi:10.1080/00036846.2011.572859

Eden, S. (1996). Public participation in environmental policy : considering scientific , counter-scientific and nonscientific contributions. Public Understanding of Science, 5, 183-204.

Godman, G. D. (2013). Countering Single-Use Bag Consumption with State Legislation: The Old Dominion Considers a New Trend. William \& Mary Environmental Law and Policy Review, 37(2), 568-592.

Hong, L. C. (2011). Environmental Tax Laws in Malaysia Today. Malaysian Accountancy Research and Education (MAREF) Review, 1(2), 9-10.

Jalil, M. A., Mian, M. N., \& Rahman, M. K. (2013). Using Plastic Bags and Its Damaging Impact on Environment and Agriculture: An Alternative Proposal. International Journal of Learning \& Development, 3(4), 1-14. doi:10.5296/ijld.v3i4.4137

Lim, M. (2012). Measuring Waste in Malaysia: A Neglected Approach. Procedia - Social and Behavioral Sciences, 42, 198-204. doi:10.1016/j.sbspro.2012.04.182

Musa, H. M., Hayes, C., Bradley, M. J., Clayson, A., \& Gillibrand, G. (2013). Measures Aimed at Reducing Plastic Carrier Bag Use: A Consumer Behaviour Focused Study. Natural Environment, 1(1), 17-23. doi:10.12966/ne.06.02.2013

Poortinga, W., Whitmarsh, L., \& Suffolk, C. (2013). The introduction of a single-use carrier bag charge in Wales: Attitude change and behavioural spillover effects. Journal of Environmental Psychology, 36, 240-247. doi:10.1016/j.jenvp.2013.09.001

Zen, I. S., Ahamad, R., \& Omar, W. (2013). No plastic bag campaign day in Malaysia and the policy implication. Environment, Development and Sustainability, 15(5), 1259-1269. doi:10.1007/s10668-013-9437-1 